HARM W. HOLLANDER

\title{
A CHILDREN'S BIBLE OR THE BIBLE FOR CHILDREN?
}

Dr Hollander is a NT biblical scholar and translator-researcher for the Netherlands Bible Society

When the Dutch common language translation (Groot Nieuws Bijbel, $G N B$ ) was published in 1983, some people thought that this new Bible translation could be read and understood by almost everyone in the Netherlands. Critics (theologians as usual!) called its vocabulary and style rather popular or even vulgar, being meant for the masses and certainly not for (well-educated) church-members. And this was mainly because there was a clear break with the old-fashioned church language used in the traditional Bible translations.

A closer look at the vocabulary and style found in the $G N B$, together with an analysis using readability formulae, led however to the conclusion that this translation is not suitable for people with a reading 
age of below 13 years. That is, young people up to the age of 12 or 13 years as well as (large) groups of adults who are handicapped (such as people born deaf, or people for whom Dutch is a second language and who find difficulty in reading books at such a level) are not able to read or understand this common language translation.

Moreover, at least in the countries of Western Europe, there are many people called "functional illiterates" or "habitual non-readers" who have almost lost the ability to read, except for what appears on television or on sandwich-boards. Television and visual aids have influenced our way of life substantially and authors of books and papers as well as Bible translators must realise that their products can be read and understood by an ever-narrowing circle of readers. These observations are certainly not new, but they must be kept in mind when we produce or analyze new Bible translations.

To make the Bible an open book for all those who find difficulty in reading texts for a reading age of 13 years and upwards, the Netherlands Bible Society started in 1976 with a new translation project: a translation of parts of the Bible from the original texts into easy-to-read Dutch (eenvoudig Nederlands). So far 1 and 2 Samuel, 1 Kings, Luke and Acts have been translated and published. Lay-out and illustrations make the portions suitable for children of the age of 8-12 years, though the translation itself can be used also by certain groups of adults. And as a matter of fact, it is being used by grown-ups, according to information we have received from a prison-chaplain, for instance, who makes use of it in his work among young prisoners.

Two years ago the NBS decided to have some more parts of the Bible translated into easy-to-read Dutch, in order to provide a wider and more representative collection of material to be used by children at home or at school. This publication will come out in 1987.

\section{Children's Bibles}

Usually, children get to know the Bible either from translations which are too difficult for them to read and understand, and which very often discourage them from going deeply into the message of the Bible when they grow up, or from so-called children's Bibles. In the Netherlands, there are by now about a hundred different titles in the category of children's Bibles, and I guess that in many other modern countries the situation is more or less the same.

To translate parts of the Bible in such a way that it can be read and understood by children might not have been necessary if the quality of these children's Bibles was satisfactory. But particularly in recent years the majority of them have been questioned by educationalists and theologians, since they think that these children's Bibles present a picture of the message of the Bible which in many ways is not true. Most of these Bibles do not give a representative selection of Bible texts; they moralise in an inadmissible way, simplify opposites like "good" and "evil", "sinners" and "righteous men", and describe God as the one 
who is absolutely almighty and who always knows best. A quotation from Ann DeVries's Story Bible for Young Children gives a fine illustration of such an approach:

The Lord always hears when people pray, and when He heard Abel, He knew that he really loved Him. God was happy to receive the offering of Abel, and He loved him too. He gave Abel a wonderful feeling of happiness and contentment.

But Cain did not love the Lord! He also brought offerings to God, which he placed on a specially prepared place, just like Abel's. First he made a pile of stones, on which he put dry branches. Then he piled some of his wheat on the sticks, and set fire to it. Cain also prayed, but he wasn't really thankful. He thought, "Why do I have to thank the Lord? Didn't I plant the wheat myself, and didn't I work hard to make it grow?"

God saw what was in Cain's heart, and He knew that Cain didn't really love Him. Because of this, the Lord did not like Cain's offering. He did not give Cain the feeling of happiness and contentment.

Cain, of course, noticed this, and he became angry with God and his brother Abel... (compare Gen 4.3-5).

This very common approach is one of the reasons why there is a growing demand for a true and faithful translation of the Bible text itself.

Another reason is that from an educational point of view it seems more desirable for children of the age of 8-12 years to be introduced to the strange world of the Bible through the reading of the texts themselves.

\section{The Bible for children}

Of course, modern educationalists do not advise and encourage reading of the Bible by children without any supervision. On the contrary, the Bible should be read by children with parents, teachers or clergymen. True, religious education should be "child-centred", starting from the children's own experiences. But that does not imply that reading the Bible and discussing biblical matters must be rejected as something fundamentally wrong. A child should learn to deal with the Bible in the right way, and this will not happen by just listening to teachers, but by actually studying the texts themselves. And the religious themes should be assimilated in the context of discussions and creative activities like painting or singing songs, and all that within a genuine Christian atmosphere.

Naturally, all this applies to children who have some experience of reading texts, that is, children of about $8-12$ years old. At a different level, there are booklets such as the 25 titles in the series "What the Bible Tells Us" and collections of some of them, which appeal to young children up to an age of 7 years. Though these contain Bible text they are first of all picture-books, appropriate for children who have just 
started learning to read.

If Bible Societies want children of 8-12 years to be introduced to Christianity and the world of the Bible, they must provide Bible translations that are appropriate for these young people. And the translation should be accompanied by booklets containing instructions for the educators and work-schemes for the children. For preference, the translation should serve as a kind of "source-book" to be used in the context of some religious educational method. This will be the case, for instance, in the Netherlands, where a commercial publishing house has planned to provide the teaching tools accompanying the Bible translation in easy-to-read Dutch.

\section{The selection of material}

The whole Bible translated for a reading age of 8-12 years would certainly be ideal; but in the context of religious education an agreed selection of material will do as well. Such a selection, however, should be quite extended, about $300-400$ pages, in order to give both educators and children the opportunity of making their own choice of which Bible passages they want to deal with. It seems preferable to maintain the biblical order, and to highlight the continuous thread of God's concern with the people of Israel and with mankind, as written down by the biblical authors. That means that examples of all important genres or types of literature, like narratives, poems, aphorisms, psalms, gospels, letters and apocalypses should be included.

But this also implies that "cruel" passages should not be left out. Though some educationalists may prefer to keep biblical stories about cruelties and sexual misbehaviour from children, I am of the opinion that children ought to get acquainted with all the aspects of the Bible. Of course, it is not recommended that children read such passages without any supervision and help. But only in this way are they introduced faithfully to the real world of the Bible. Even for us grown-ups, there are a lot of passages in the Bible that raise questions which are not so easily answered. But just passing over them is not the right way of dealing with the Bible. Some six years ago I was writing a series of articles about the Bible and the history of Israel for a Dutch newspaper. When I came to the story of Ehud in Judges 3 I was not allowed to have it published: non-Christian people might have got an unfavourable impression of the Word of God!

\section{Translation method}

It is a matter of fact that the biblical writings, or at least the majority of them, were not written for children. But that does not mean that they should not be read by children. There are lots of books written either for children or for adults but read by both. And in many other cases, books originally written for grown-ups are adapted a little to make them appropriate for reading by children.

Similarly, Bible passages should be made appropriate to be read by 
children of the age of 8-12 years-but not in the way the vast majority of children's Bibles handle them. In a Bible for children the text ought to be translated, but translated in such a way that it is equivalent to the original text in the understanding and feeling which the young new readers get from it. This means, for example, that an exciting biblical story like the Genesis story about Joseph, must not be rendered into a tedious and boring narrative. On the contrary, such a text should be translated with the help of all the elements of the language which an ordinary writer has at his disposal to make an exciting story.

Much information that was known to the original readers but was not stated in the text must be expressed in words for the translation to be understood by children. On the other hand, we should not hesitate to simplify the relationship between phrases or clauses when we know that they will not be grasped by children anyway.

Such translation is still far from being what is sometimes called a "paraphrase". There should not be any hint of additions to the text that breathe a particular ideological or theological spirit. And passages should not be adapted in order to make them more exciting than they really are, or be left out because they do not fit in with the translator's ideas. Nevertheless, the translation ought to be clear.

Much inventiveness is therefore demanded of the translator, the more so - as footnotes should be avoided in a translation for children. Naturally, some "technical terms" such as Pharisees, Sadducees, circumcision, altar or of ferings may be explained in a special list. And it may be felt useful or even essential to add some geographical and historical information between the passages selected or to say something about the relevant books of the Bible. But apart from that, the translation itself should be easy to understand.

\section{Translation level}

A translation for a reading age of 8-12 years calls for some specific translation rules, which are, however, not to be applied too rigidly. Sentences should have a rather simple grammatical and syntactical structure and contain no more than 10-12 words. Negative phrases and passive forms should be introduced only with the utmost caution; the number of modifiers should be limited to one; and idiomatic peculiarities should be avoided completely. The same is true of words of low frequency-to be checked with the help of published word frequency lists. For preference, words of as few syllables as possible are to be used. Finally, the style should be direct and lively. That also implies that the number of impersonal pronouns must be reduced to a minimum and that personal and possessive pronouns are used as much as possible. This adds considerably to the so-called "human interest score", another element that affects the readability of a text.

Readability tests (Cloze techniques or the well-known Flesch formula) will bring to light whether the translation meets the needs of children of 8-12 years old. In the Netherlands, for instance, such tests have revealed 
that the new translation in easy-to-read Dutch has indeed a reading age level of 8-12 years and is far easier to understand than the traditional Bible translations or the new common language translation.

\section{Illustrations}

A Bible for children should be copiously illustrated. In all modern school books illustrations play a dominant role and a Bible text-book should not be an exceptional case. For preference, the illustrations-in full colour-would be scattered through the text instead of filling whole pages. They should highlight the main theme of the relevant passages and, if possible, give some extra information: pictures and texts should be fully integrated. This should all be done in order to try to overcome the idea many children as well as adults have-that the Bible is a boring book. In vocabulary, style, layout and illustrations, a Bible text-book for children should be in line as much as possible with other modern schoolbooks. Only in its actual content will it reveal the unique character of the Word of God. 